\title{
JAMINAN KEBENDAAN DAN JAMINAN PERORANGAN SEBAGAI UPAYA PERLINDUNGAN HUKUM BAGI PEMILIK PIUTANG
}

\author{
Niken Prasetyawati, Tony Hanoraga
}

\begin{abstract}
Abstrak
Dalam mewujudkan tujuan nasional kegiatan dalam bidang ekonomi merupakan prioritas utama untuk meningkatkan taraf hidup dan kesejahteraan rakyatnya, berbagai kebijakan dibuat untuk memacu kegiatan ekonomi,memberikan kemudahan pada pelaku ekonomi untuk mengembangkan usahanya.Pengembangan dunia usaha membutuhkan fasilitas modal dalam jumlah besar, dana berupa modal dapat diperoleh dari berbagai sumber, dapat berupa modal dari setoran para pendiri usaha ataupun dari utang yang diperoleh dari sumber sumber seperti, bank, lembaga pembiayaan , pasar uang, pasar modal,dll.Dengan semakin pesatnya kegiatan ekonomi dan penyaluran dana pinjaman ,sumber sumber pemberi utang atau yang sering disebut kreditor juga membutuhkan perlindungan hukum dalam hal para pengutang atau yang biasa disebut debitor ingkar janji. Lembaga jaminan dibutuhkan sebagai upaya perlindungan bagi pemberi utang tersebut.
\end{abstract}

Kata kunci : kegiatan ekonomi, kreditor, debitor, lembaga hak jaminan .

Indonesia sebagai salah satu negara berkembang berupaya keras untuk bisa mewujudkan tujuan nasionalnya yaitu meningkatkan kesejahteraan rakyatnya . Dalam upaya ini bidang ekonomi merupakan prioritas utama untuk meningkatkan taraf hidup dan kesejahteraan rakyat .Berbagai kebijakan dibuat untuk meningkatkan dan memacu kegiatan ekonomi, memberikan kemudahan -kemudahan pada pelaku ekonomi untuk merentangkan sayap usahanya. Pengembangan dunia usaha tentu saja sangat membutuhkan fasilitas modal dalam jumlah yang besar ,untuk itu dibutuhkan lembaga terkait yang memberikan dukungan dana bagi kegiatan suatu usaha.Dana bagi suatu perusahaan dalam menjalankan kegiatan usahanya dapat diperoleh dari berbagai sumber, dapat berupa modal dan utang. Dana berupa modal diperoleh dari para pendirinya berupa setoran modal pendiri dan diperoleh dari pemodal [investor]. Dana berupa utang dapat diperoleh dari sumber sumber seperti bank-bank, lembaga -lembaga pembiayaan, pasar uang, pasar modal.

Sumber -sumber yang memberikan utang kepada perusahaan atau perorangan tersebut disebut Kreditor,dengan kata lain perusahaan ataupun jsh Jurnal Sosial Humaniora, Vol 8 No.1, Juni 2015 
perorangan tersebut adalah Debitor dari para Kreditor tersebut. Dengan semakin derasnya lalu lintas penyaluran dana pinjaman tersebut maka para Kreditor ini juga membutuhkan perlindungan dalam hal Debitor cidera janji . Aturan hukum telah menyediakan sarananya yaitu seperti yang tertuang dalam ketentuan - ketentuan Hukum Jaminan yang dapat dicermati dalam Kitab Undang-undang Hukum Perdata.Jaminan secara hukum mempunyai fungsi untuk mengkover utang, karena itu jaminan merupakan sarana perlindungan bagi para Kreditor yaitu kepastian akan pelunasan utang Debitor atau penjamin Debitor . Jaminan kebendaan dan jaminan perorangan timbul dari perjanjian yang bertujuan untuk menjamin kepastian hukum bagi Kreditor atas pelunasan utang atau pelaksanaan suatu prestasi sebagaimana telah diperjanjikan oleh Debitor atau pihak ketiga.

Dari uraian latar belakang diatas maka permasalahan yang dibahas adalah :

1. Apakah jaminan kebendaan dan jaminan perorangan mempunyai aspek hukum yang sama dalam rangka memberikan perlindungan hukum bagi para Kreditor atas kepastian pelunasan utang para Debitornya ,Adakah perbedaan dari kedua bentuk jaminan tersebut bila dikaitkan dengan kepastian pelunasan utang?

2. Bagaimana eksekusi kedua bentuk jaminan tersebut apabila terjadi Debitor cidera janji ?

\section{SEJARAH HUKUM JAMINAN DI INDONESIA}

Keadaan lembaga jaminan di Indonesia setelah Perang Dunia II mengalami perkembangan yang lamban, dalam arti tidak terjadi pembaharuan hukum ataupun pengaturan- pengaturan yang baru mengenai lembaga jaminan yang telah lama dikenal sejak berlakunya Kitab Undang-undang Hukum Perdata , juga tidak terjadi pengaturan hukum mengenai lembaga jaminan yang telah lama tumbuh dan berkembang dalam masyarakat dan telah lama diakui oleh Yurisprudensi, misalnya lembaga jaminan fidusia, lembaga sewa beli,dan seterusnya (Sri Soedewi Masjchoen $1980: 3)$

Jaminan kebendaan benda bergerak diikat dengan hak gadai sebagaimana diatur dalam Kitab Undang- undang Hukum Perdata pada Buku Kedua Bab XX pasal 1150 sampai dengan pasal 1161. Adapun obyek hak gadai adalah benda atau 
barang bergerak baik bertubuh/ berwujud / berbentuk (lichamelijke zaken ) maupun tidak bertubuh/ berwujud/ berbentuk (onlichamelijke zaken). Setelah berlakunya Undang- undang No. 5 Tahun 1960 tentang Peraturan Dasar Pokok-Pokok Agraria , hak - hak adat yang bersifat bertentangan dengan ketentuan- ketentuan undangundang tersebut tetapi berhubung dengan keadaan masyarakat sekarang ini belum dapat dihapuskan diberi sifat sementara dan akan diatur. Contohnya adalah hak gadai yang disebut dalam pasal 53 jo pasal 52 ayat(2) daan ayat (3) Undang- undang Pokok Agraria yang menentukan, bahwa hak gadai sebagai hak yang bersifat sementara diatur untuk membatasi sifat- sifatnya yang bertentangan dengan Undang - undang Pokok Agraria dan hak gadai itu diusahakan hapusnya didalam waktu yang singkat, karena didaalam hak gadai ada unsur- unsurnya yang bersifat pemerasan. (Rachmadi Usman 1998 :5)

Jaminan kebendaan hak hipotik pengaturannya terdapat dalam Kitab Undang- undang Hukum Perdata Buku Kedua ,yaitu pasal 1162 sampai dengan pasal 1170, pasal 1173 sampai dengan pasal 1185, pasal 1189 sampai dengan pasal 1194 dan pasaal 1198 sampai dengan pasal 1232. Pasal pasal lainnya yang mengatur hipotik sejak semula belum pernah berlaku

Hipotik adalah suatu lembaga jaminan yang diperuntukan bagi khusus tanah yyang tunduk pada hukum barat, sedangkan jaminan yang sama bagi tanah- tanah Indonesia telah dikeluarkan S. 1908-542 jo S. 1909- 586, yaitu Regeling betreffede het creditverband yang mulai berlaku sejak 1 Januari 1910 sebagaimana telah diubah dan ditambah dengan S.1917 - 497 jo S. 1917 -645, S. 1925-434, S.1939-287, S. 1931-168 jo S. 1931- 423, S. 1937- 190 jo S. 1931-191, S. 1938- 373 jo S. 1938264, menurut peraturan mana terhadap tanah - tanah hak milik Indonesia dapat dijaminkan dengan credietverband. (Abdurrahman 1979 :173) Sejak tahun 1960 telah terjadi perubahan mendasar terhadap Kitab Undang- undang Hukum Perdata Indonesia., dengan disahkannya Undang- undang Pokok Agraria yang bermaksud mengadakan unifikasi hukum pertanahan nasional . Perubahan yang besar terlihat pada Buku Kedua Kitab Undang -undang Hukum Perdata , dalam diktum Undangundang Pokok Agraria memutuskan Buku Kedua KUH Perdata sepanjang yang mengenai bumi,air serta kekayaan alam yang terkandung didalamnya, kecuali 
ketentuan -ketentuan mengenai hipotik yang masih berlaku pada mulai berlakunya Undang - undang Pokok Agraria dinyatakan tidak berlaku.

Undang- undang Pokok Agraria dalam hubungan dengan lembaga hak jaminan menggariskan sebagai berikut :

a. Mencabut Buku Kedua Kitab Undang- undang Hukum Perdata sepanjang yang mengenai bumi, air serta kekayaan alam yang terkandung didalamnya, kecuali ketentuan- ketentuan mengenai hipotik yang masih berlaku pada mulai berlakunya Undang- undang Pokok Agraria

b. Undang- undang Pokok Agraria menentukan adanya lembaga hak jaminan atas tanah yang diberi nama dengan sebutan " hak tanggungan ", yang untuk selanjutnya akan diatur tersendiri, yaitu dengan Undang -undang Hak Tanggungan ( pasal 51).

c. Adapun hak- hak atas tanah yang dapat dibebani dengan hak tanggungan tersebut adalah hak milik, hak guna usaha,dan hak guna bangunan sebagaimana tersebut dalam pasal- pasal 25,33 dan 39 Undang- undang Pokok Agraria

d. Selama Undang- undang Hak Tanggungan yang dimaksud belum terbentuk maka untuk sementara yang berlaku adalah ketentuan- ketentuan mengenai hipotik tersebut dalam Kitab Undang- undang Hukum Perdata dan Credietverband tersebut dalam S. 1908-542 sebagai yang telah diubah dengan S. 1937- 190 (pasal 57).

Credietverband merupakan suatu lembaga jaminan yang diciptakan untuk memberikan kesempatan kepada golongan pribumi untuk dapat memperoleh kredit dari lembaga - lembaga perbankan, dengan jaminan hak- hak atas tanah yang bukan merupakan hak- hak yang dikenal dalam Kitab Undang- undang Hukum Perdata yaitu hak- hak atas tanah menurut hukum adat yang mereka punyai. Karena hipotik hanya dapat diterapkan pada hak- hak atas tanah yang dikenal dalam Burgerlijk Wetboek ( J. Satrio 1993 ). Oleh karena itu pemerintah Hindia Belanda memandang perlu menciptakan lembaga hukum jaminan atas hak atas tanah dengan jalan mereduksi lembaga dan ketentuan - ketentuan mengenai hipotik.

Hak jaminan yang lain adalah fidusia ( fiduciare-eigendomsoverdracht) ,yang diciptakan melalui Yurisprudensi. Fidusia adalah hak jaminan berupa 
penyerahan hak atas benda berdasarkan kepercayaan yang disepakati sebagai jaminan bagi pelunasan utang. Jadi fidusia pada hakekatnya adalah penyerahan hak milik atas suatu benda kepada kreditor dengan perjanjian bahwa penyerahan tersebut hanya untuk menjamin atas pembayaran kembali uang pinjaman . Debitor dan Kreditor saling percaya bahwa penyerahan benda tersebut hanya untuk jaminan .Subekti mengemukakan, bahwa begitu sukarnya memperjuangkan kedudukan fidusia sebagai hak kebendaan ,disebabkan karena dalam hukum perdata sudah lama dianut suatu sistem, bahwa hak kebendaan itu terbatas jumlahnya dan hanya dapat diciptakan oleh peraturan undang-undang. Pada awalnya dianggap sebagai gadai yang gelap ( klandestio ), tetapi karena kebutuhan masyarakat yang begitu mendesak akan adanya suatu bentuk jaminan barang bergerak yang tetap dapat dikuasai oleh si berutang, yaitu barang-barang yang diperlukan untuk menjalankan usaha , maka akhirnya fidusia ini diberikan legalitas. ( Subekti 1991 : 66).

Untuk melaksanakan amanat Undang-undang Pokok Agraria maka pada tanggal 9 April 1996 telah disahkan Undang- undang No. 4 Tahun 1996 tentang Hak Tanggungan Atas Tanah Beserta Benda-benda Yang Berkaitan Dengan Tanah.,dengan demikian maka ketentuan-ketentuan mengenai hipotik dan credietverband dalam Buku Kedua Kitab Undang -undang Hukum Perdata dan S. 1908-542 serta perubahannya dinyatakan tidak berlaku. Demikian juga dengan lembaga jaminan fidusia telah diatur dalam Undang- undang No. 42 Tahun 1999.

\section{PEMBEDAAN LEMBAGA JAMINAN}

Perlu dipahami bahwa lapangan hukum jaminan adalah sangat luas . Jaminan termasuk dalam hukum benda,secara teoritis, jaminan dibagi menjadi dua yaitu jaminan umum dan jaminan khusus. Jaminan khusus dibagi lebih lanjut menjadi jaminan kebendaan dan jaminan perorangan. Selanjutnya jaminan kebendaan dibagi menjadi jaminan benda bergerak dan benda tetap. Jaminan benda bergerak dibagi menjadi gadai dan fidusia, sedangkan jaminan benda tetap dibagi menjadi hak tanggungan atas tanah, fidusia dan hak tanggungan bukan atas tanah . Jadi jaminan merupakan satu sistem yang mencakup hak tanggungan atas tanah. ( Sudikno Mertokusumo 1996 : 2 ). 
Pada prinsipnya menurut hukum, segala harta kekayaan debitor akan menjadi jaminan bagi utangnya dengan semua kreditor. Kitab Undang -undang Hukum Perdata pada pasal 1131 menyatakan bahwa segala kebendaan si berutang baik yang bergerak maupun yang tidak bergerak, baik yang sudah ada maupun yang baru akan ada dikemudian hari, menjadi tanggungan untuk segala perikatannya perseorangan . Kekayaan debitor yang dimaksud meliputi benda bergerak maupun benda tetap, baik yang sudah ada saat perjanjian utang piutang diadakan maupun yang baru akan ada dikemudian hari yang akan menjadi milik debitor setelah perjanjian utang piutang diadakan . Jadi dengan demikian tanpa terkecuali seluruh harta kekayaan debitor akan menjadi jaminan umum atas pelunasan utangnya, baik yang telah diperjanjikan maupun yang tidak diperjanjikan sebelumnya. Jaminan umum ini dilahirkan karena undang- undang ,sehingga tidak perlu ada perjanjian jaminan sebelumnya.

J. Satrio mengemukakan, bahwa dari pasal 1131 KUH Perdata dapat disimpulkan asas -asas hubungan ekstern kreditor sebagai berikut :

a. Seorang kreditor boleh mengambil pelunasan dari setiap bagian dari harta kekayaan debitor.

b. Setiap bagian kekayaan debitor dapat dijual guna pelunasan tagihan kreditor.

c. Hak tagihan kreditor hanya dijamin dengan harta benda debitor saja, tidak dengan " persoon debitor " ( J. Satrio 1993 : 4-5 )

Dalam jaminan yang bersifat umum, semua kreditor mempunyai kedudukan yang sama terhadap kreditor - kreditor lain, tidak ada kreditor yang diutamakan atau diistimewakan dari kreditor- kreditor lain. Pelunasan utangnya dibagi secara "seimbang" berdasarkan besar kecilnya jumlah tagihan masing- masing kreditor dibandingkan dengan jumlah keseluruhan utang debitor. Hal ini ditegaskan dalam pasal 1132 KUH Perdata bahwa kebendaan tersebut menjadi jaminan bersamasama bagi semua orang yang mengutangkan padanya, hasil penjualan benda - benda itu dibagi- bagi menurut keseimbangan, yaitu menurut besar kecilnya piutang masing- masing kecuali apabila diantara para berpiutang itu ada alasan yang sah untuk didahulukan. Pasal 1132 KUH Perdata juga memberikan kemungkinan sebagai pengecualian adanya kedudukan yang diutamakan kapada kreditor tertentu 
terhadap kreditor- kreditor lain . Adapun kreditor yang diutamakan tersebut berdasarkan pasal 1133 KUH Perdata adalah mereka yang memiliki hak- hak yang dilahirkan karena piutang yang diistimewakan (privilege ), dari gadai( pand ) dan dari hipotik. Dengan demikian dapat disimpulkan , bahwa kedudukan para kreditor ditentukan oleh jenis jaminan yang dipegangnya.

Privilege bukan jaminan yang bersifat kebendaan dan bukan jaminan yang bersifat perorangan tetapi memberi jaminannya juga.. Menurut pasal $1134 \mathrm{KUH}$ Perdata yang dimaksud privilege ialah suatu hak yang oleh undang- undang diberikan kepada seseorang berpiutang sehingga tingkatnya lebih tinggi daripada orang berpiutang lainnya, semata- mata berdasakan sifatnya piutang, jadi privilege dilahirkan karena undang-undang sedang hak gadai, hipotik karena diperjanjikan sebelumnya, sehingga kedudukan gadai dan hipotik lebih tinggi daripada privilege, kecuali dalam hal- hal mana undang- undang ditentukan sebaliknya.

Jaminan umum ini dalam praktik perkreditan ( perjanjian peminjaman uang ) tidak memuaskan bagi kreditor, kurang menimbulkan rasa aman dan kurang terjamin bagi kredit yang diberikan. Dengan jaminan umum tersebut kreditor tidak mengetahui secara persis berapa jumlah harta kekayaan debitor yang ada sekarang dan yang akan ada dikemudian hari, serta kepada siapa saja debitor berutang, sehingga khawatir hasil penjualan harta kekayaan debitor nantinya tidak cukup untuk melunasi utang- utangnya . ( Gatot Supramono 1995 :59 ) Untuk itu para kreditor mempunyai alternatif perangkat jaminan yang disediakan oleh pembentuk undang- undang yaitu jaminan khusus yang obyeknya juga milik debitor hanya saja ditunjuk secara tertentu dan diperuntukkan bagi kreditor tertentu.yang bersifat kebendaan maupun yang bersifat perorangan. Jaminan khusus ini timbul karena adanya perjanjian yang khusus diadakan antara kreditor dan debitor ( Moch. Isnaeni 1996 :34). Jadi untuk menjamin pelunasan utang debitor maka dibuat perjanjian jaminan khusus antara kreditor tertentu dengan debitor yang bisa berupa perjanjian jaminan kebendaan ataupun perjanjian jaminan perorangan . 


\section{ASPEK HUKUM JAMINAN KEBENDAAN DAN PERORANGAN}

Jaminan kebendaan dan jaminan perorangan timbul dari perjanjian yang bertujuan untuk adanya kepastian hukum bagi kreditor atas pelunasan utang atau pelaksanaan suatu prestasi tertentu sebagaimana telah diperjanjikan oleh debitor atau pihak ketiga, jaminan secara yuridis materiil mempunyai fungsi untuk pelunasan utang apabila debitor ingkar janji.

Dalam jaminan kebendaan benda obyek jaminan khusus diperuntukan sebagai upaya preventif untuk berjaga- jaga apabila suatu ketika terjadi debitor ingkar janji. Pemilikan benda obyek jaminan tidak beralih kepada kreditor karena terjadinya penjaminan tersebut. Dengan demikian dalam perjanjian jaminan kebendaan, benda tetap menjadi milik debitor, benda hanya disiagakan untuk berjaga- jaga terhadap kemungkinan terjadi debitor ingkar janji.

Dalam hukum jaminan kebendaan apabila benda obyek jaminan beralih kepada kreditor ( menjadi milik kreditor) maka perjanjian jaminan tersebut batal demi hukum ( pasal $1154 \mathrm{KUH}$ Perdata bagi gadai, pasal 1178 ayat (1) KUH Perdata bagi hipotik, pasal 12 UU No. 4 tahun 1996 tentang Hak Tanggungan, pasal 33 UU No. 42 tahun 1999 tentang Fidusia ), sehingga dengan demikian jelas bahwa dalam hukum jaminan kebendaan tidak diperkenankan pengalihan hak atas benda obyek jaminan kepada kreditor.

Jaminan perorangan ( borgtocht/ personal guarantee) adalah jaminan berupa pernyataan kesanggupan yang diberikan oleh seorang pihak ketiga guna menjamin pemenuhan kewajiban - kewajiban debitor yang bersangkutan kepada kreditor , apabila debitor cidera janji. Jaminan semacam ini dasarnya adalah penanggungan utang yang diatur dalam pasal 1820-111850 KUH Perdata. Pada perkembangannya , jaminan perorangan juga dipraktekkan oleh perusahaan yang menjamin utang perusahaan lainnya . Bank dalam hal ini serimg menerima jaminan serupa , yang sering disebut Corporate Guarantee.

Perbedaan antar jaminan perorangan dengan jaminan kebendaan adalah:

a. Dalam jaminan perorangan terdapat Pihak Ketiga yang menyanggupi untuk memenuhi perikatan debitor bila debitor tidak dapat memenuhi kewajibannya. 
b. Dalam jaminan kebendaan hanya harta kekayaan debitor sajalah yang dapat dijadikan jaminan bagi pelunasan kredit apabila debitor cidera janji.

\section{Perjanjian Jaminan Kebendaan dan Perorangan}

Perjanjian jaminan kebendaan selalu merupakan perbuatan memisahkan suatu bagian dari kekayaan seorang yang bertujuan untuk menjaminkan dan menyediakannya bagi pemenuhan kewajiban seorang debitor. Karena dalam jaminan kebendaan yang dijadikan obyek jaminan adalah benda maka berlaku asas - asas hak jaminan kebendaan seperti dibawah ini :

1. Hak jaminan ini memberikan kedudukan yang didahulukan bagi kreditor pemegang hak jaminan ini terhadap para kreditor yang lainnya, adanya hak Preferen.

2. Hak jaminan ini merupakan hak accesoir terhadap perjanjian pokok yang dijamin dengan jaminan tersebut., artinya hapusnya bergantung pada perjanjian pokoknya.

3. Benda yang menjadi obyek jaminan adalah benda bergerak maupun benda tidak bergerak .

4. Mempunyai sifat kebendaan ( real right ) segaimana diatur dalam pasal 528 KUH Perdata . Sifat daripada Hak Kebendaan itu sendiri yaitu : Absolut yaitu dapat dipertahankan pada setiap orang,dan Droit de suite yaitu, Hak Kebendaan mengikuti pada siapapun dia berada.

Jaminan kebendaan merupakan hak mutlak ( absolut ) atas suatu benda tertentu yang menjadi obyek jaminan suatu utang, yang suatu waktu dapat diuangkan bagi pelunasan utang debitor apabila debitor ingkar janji .Kekayaan tersebut dapat berupa kekayaan debitor itu sendiri atau kekayaan orang ketiga, penyediaan atas benda obyek jaminan ddalam perjanjian jaminan kebendaan adalah untuk kepentingan dan keuntungan kreditor tertentu yang telah memintanya, sehingga memberikan hak atau kedudukan istimewa kepada kreditor tersebut. Kreditor tersebut mempunyai kedudukan sebagai kreditor Preferen yang didahulukan daripada kreditor yang lain dalam pengambilan pelunasan piutangnya dari benda obyek jaminan, bahkan dalam kepailitan debitor, ia mempunyai kedudukan sebagai kreditor separatis. 
Sebagai kreditor separatis, ia dapat bertindak seolah- olah tidak ada kepailitan pada debitor, karena ia dapat melaksanakan haknya untuk melakukan parate eksekusi. Ketentuan dalam pasal 1133 KUH Perdata hanya memberikan hak preferen kepada kreditor pemegang Hipotik dan Gadai namun dewasa ini di Indonesia terdapat lembaga lain yang mempunyai kedudukan preferen yaitu Hak Tanggungan dan Fidusia. Sehingga dengan demikian hak jaminan kebendaan dimiliki oleh pemegang Hak Tanggungan, Hipotik ( dewasa ini antara lain untuk kapal laut dan pesawat udara ), Gadai dan Fidusia . Dalam ketentuan kepailitan apabila terdapat kreditor preferen (pemegang Hak Tanggungan , Hipotik , Gadai dan Fidusia ) maka kreditor tersebut merupakan kreditor separatis dan dapat melaksanakan hak mereka seolah- olah tidak ada kepailitan pada debitor, pasal 56 ayat (1) UU No. 4 tahun 1998.( Djuhaendah Hasan, 2000 :18 ).

Hak jaminan perorangan timbul dari perjanjian jaminan antara kreditor dengan pihak ketiga . Perjanjian jaminan perorangan merupakan hak relatif yaitu hak yang hanya dapat dipertahankan terhadap orang tertentu yang terkait dalam perjanjian . Dalam perjanjian jaminan perorangan, pihak ketiga bertindak sebagai penjamin dalam pemenuhan kewajiban debitor, berarti perjanjian jaminan perorangan merupakan janji untuk memenuhi kewajiban debitor, apabila debitor ingkar janji . Dalam jaminan perorangan tidak ada benda tertentu yang diikat dalam jaminan, sehingga tidak jelas benda apa dan yang mana milik pihak ketiga yang dapat dijadikan jaminan apabila debitor ingkar janji , dengan demikian para kreditor pemegang hak jaminan perorangan hanya berkedudukan sebagai kreditor konkuren saja. Apabila terjadi kepailitan pada debitor maupun penjamin ( pihak ketiga ), akan berlaku ketentuan jaminan secara umum yang tertera dalam pasal 1131 dan 1132 KUH Perdata.

Hak jaminan perorangan tidak memberikan preferensi kepada kreditor sehingga kreditor akan bersaing dengan kreditor lain dalam pemenuhan kewajiban debitor. Hak jaminan perorangan hanya dapat dipertahankan terhadap orang atau pihak ketiga yang terikat dalam perjanjian saja dan tidak mengikat setiap orang sebagaimana perjanjian kebendaan yang mempunyai sifat absolut. Dalam praktek , perjanjian jaminan perorangan kurang disukai karena para kreditor hanya 
berkedudukan sebagai kreditor konkuren yang harus bersaing dengan kreditor lain dalam pemenuhan kewajiban debitor, dan karena pihak ketiga juga tidak mengikatkan harta tertentu dalam perjanjian sering terjadi pihak ketiga melakukan pengingkaran terhadap kesanggupannya. Menurut Subekti karena tuntutan kreditor terhadap penanggung tidak diberikan suatu privilege atau kedudukan istimewa diatas tuntutan kreditor lainnya dari si penanggung ( Subekti $1986: 27$ ).

Perjanjian jaminan perorangan dapat berupa penanggungan / borgtocht, bank garansi, jaminan perusahaan. Pasal 1820 KUH Perdata menyebutkan bahwa penanggungan adalah persetujuan dengan mana seseorang pihak ketiga guna kepentingan debitor mengikatkan diri untuk memenuhi perikatan debitor apabila ia tidak memenuhinya . Perjanjian jaminan perorangan sebagaiman perjanjian jaminan lainnya merupakan perjanjian accessoir sebagaimana disebutkan dalam pasal 1821 ayat (1) KUH Perdata. Meskipun dengan segala kelemahan yang ada pada perjanjian jaminan perorangan, kreditor akan merasa lebih aman daripada tidak ada jaminan sama sekali ,karena dengan adanya jaminan perorangan kreditor dapat menagih tidak hanya pada debitor tetapi pada pihak ketiga yang menjamin yang kadangkadang terdiri dari beberapa orang ataupun suatu perusahaan

\section{EKSEKUSI JAMINAN}

Dengan adanya perikatan yang dijalin para pihak maka hak dan kewajiban akan segera muncul sebagai hasil kesepakatan bersama. Masing - masing pihak harus memenuhi kewajibannya agar perikatan berjalan sesuai dengan yang diharapkan . Manakala ada salah satu pihak yang enggan memenuhi kewajibannya maka pihak lain akan menderita rugi. Kalau hal ini terjadi maka pihak kreditor wenang untuk menuntut pemenuhan kewajiban tersebut dari debitor, kalau perlu minta bantuan hukum untuk melakukan daya paksa. Namun daya paksa hukum ini bukan berarti menekan dengan kekerasan secara phisik kepada debitor untuk melakukan kewajibannya. Dengan kata lain tidak dapat dilakukan paksaan secara langsung. (Moch. Isnaeni $1996: 51$ ).

Bila terjadi seorang debitor tidak mau memenuhi kewajibannya secara sukarela , biasanya kreditor sudah cukup puas dengan adanya ganti rugi berupa 
sejumlah uang tertentu yang dianggap selaku penukar kewajiban debitor yang tak dipenuhinya itu. Tetapi dalam beberapa hal lain melalui bantuan hukum kreditor dapat memperoleh apa saja seperti yang diperjanjikan . Dalam peristiwa seperti itu dikatakan telah ada eksekusi riil. Hanya saja prakteknya apa yang dimaksud dengan eksekusi riil merupakan suatu ujud prestasi yang diperoleh kreditor melalui bekerjanya daya paksa hukum, yang sifatnya mirip dengan apa yang dibayangkan pada waktu menutup perikatan.

Perjanjian kredit sebagai suatu perikatan sudah dijamin oleh undang- undang dengan harta benda milik debitor seperti yang diatur dalam pasal $1131 \mathrm{KUH}$ Perdata. Tetapi bila debitor tidak memenuhi janjinya maka harta itulah yang akan dimintakan oleh kreditor kepada hakim untuk dijual lelang dan hasilnya dipergunakan untuk melunasi utang debitor.Proses ini jelas akan melewati jalur yang sangat panjangdan kadang juga tidak gampang. Bisa saja debitor mengajukan banding dan kemudian dilanjutkan dengan kasasi yang bisa memakan waktu yang tidak sedikit. Dan kalau kemudian kreditor dimenangkan maka masih harus melalui proses eksekusi yang mungkin juga menghadapi hambatan yang tidak ringan. Untuk mengantisipasi hal seperti ini maka pembentuk undang - undang menyediakan sarana lain yaitu adnya ketentuan jaminan khusus sebagaimana yang tercantum dalam Buku Kedua KUH Perdata. Sejalan dengan ketentuan - ketentuan mengenai jaminan khusus ini maka biasanya ditentukan berapa besar pinjaman yang akan diberikan kepada seseorang dan nantinya akan benar- benar dapat kembali utuh beserta bunganya ditempuhlah cara dengan menunjuk secara tegas benda tertentu milik si peminjam yang seketika itu dapat ditaksir nilainya untuk dipakai sebagai jaminan dan ini bisa dipakai dengan berdasarkan pada kesepakatan yang kemudian dituangkan dalam parjanjian khusus untuk kemudian disertakan sebagai pendukung perjanjian pinjam meminjam yang mendahuluinya. Seandainya dikemudian hari debitor tak mampu membayar, maka benda yang bersangkutan selaku jaminan dapat segera dijual dimuka umum untuk dibayarkan kepada yang meminjamkan sebagai gantinya.

Apabila dalam suatu perjanjian pinjam meminjam atau perjanjian kredit kemudian diikuti dengan perjanjian jaminan khusus yang berobyek benda atau 
jaminan kebendaan, maka benda tertentu itu diikat secara khusus untuk keperluan pemenuhan perikatan yang tertentu juga yakni perjanjian kredit itu sendiri dan diperuntukkan bagi kreditor yang tertentu pula. Dalam hal pelunasan utang, pihak pihak lain tak ada kewenangan ikut menikmati hasil penjualan benda yang bersangkutan, kecuali ditentukan lain oleh undang- undang. Jadi dengan disediakannya jaminan kebendaan dimaksudkan untuk mempermudah pelunasan pinjaman yang telah diberikan oleh kreditor bila sewaktu- waktu debitor wanprestasi, untuk tercapainya tujuan tersebut haruslah didukung dengan eksekusi yang mudah dan sederhana agar tidak banyak waktu dan biaya yang dikeluarkan.

Apabila benda yang dijadikan jaminan adalah benda bergerak maka gadai yang akan dipakai, maka kreditor pemegang gadai sehubungan dngan masalah pelunasan utang akan memiliki hak parate eksekusi sebagaimana ditetapkan oleh pasal 1155 KUH Perdata. Hak ini sepanjang tidak diperjanjikan lain lahir demi undang- undang sejak debitor wanprestasi. Dalam parate eksekusi kreditor diberi wewenang untuk menjual benda jaminan dimuka umum dengan memperhatikan kebiasaan setempat dengan syarat - syarat yang lazim berlaku. Untuk keperluan menjual benda jaminan tidak diperlukan adanya title eksekutorial, kreditor tidak memerlukan bantuan Pengadilan. Apabila obyek jaminan gadai ini adalah berbentuk saham maka saham tersebut akan dijual ke pasar bursa dengan memperhatikan ketentuan- ketentuan yangberlaku disitu.

Dalam perjanjian jaminan hipotik, kreditor juga bisa memiliki wewenang untuk menjual sendiri benda jaminan, namun ini harus diperjanjikan sebagaimana ditentukan oleh pasal 1178 ayat (2) KUH Perdata . Berarti kewenangan bukan lahir dari undang - undang, tetapi harus dimunculkan dalam perjanjian oleh para pihak dalam ujud pemberian kuasa oleh debitor kepada kreditor untuk menjual sendiri benda jaminan bila debitor wanprestasi.hal ini sangat menguntungkan kreditor karena pelunasan dilakukan dengan mudah dan sederhana. Sebenarnya dengan grosse akte hipotek sesuai dengan ketentuan pasal 234 HIR , kreditor juga memiliki wewenang untuk menjual benda jaminan dikarenakan akte tersebut memiliki kekuatan eksekutorial, dengan fiat pengadilan maka dapat mengambil pelunasan dari pelelangan yang dilakukan juru lelang. 
Dengan disahkannya UU No. 4 Tahun 1996 tentang Hak Tanggungan maka bagi kreditor pemegang hak tanggungan berdasarkan pasal 26 Undang- undang Hak Tanggungan ditegaskan bahwa dalam jaminan kebendaan dengan hak tanggungan maka sertifikat hak tanggungan merupakan pengganti grosse akte hipotek. Dengan mengacu pasal 20 Undang- undang Hak Tanggungan maka ada dua kemungkinan yang dapat dilakukan oleh kreditor apabila debitor cidera janji yaitu :

1. melaksanakan parate eksekusi dan

2. berdasarkan title eksekutorial yang terdapat dalam sertifikat hak tanggungan dijual dalam pelelangan umum

Dalam hal jaminan khusus yang berupa jaminan perorangan maka eksekusi terhadap perjanjian jaminan ini sangat sulit karena hanya ada kesanggupan dari penjamin yaitu seseorang pihak ketiga atau suatu perusahaan tertentu yang dijadikan jaminan ,tanpa didukung dengan suatu perjanjian jaminan kebendaan yang menikat pihak ketiga sebagai penjamin maka jaminan perorangan tidaklah mungkin dapat dieksekusi

\section{Kesimpulan}

-Fungsi jaminan adalah untuk menjamin pelunasan utang apabila debitor wanprestasi terutama akan jelas tampak pada perjanjian jaminan kebendaan karena adanya obyek jaminan yang berupa benda tertentu,sehingga hak ini bersifat absolut, sedangkan pada jaminan perorangan hanya ada kesanggupan pihak ketiga untuk menjamin pemenuhan kewajiban debitor, tanpa didukung perjanjian jaminan kebendaan yang mengikat pihak ketiga tersebut maka jaminan perorangan hanya merupakan hak yang bersifat relatif seperti halnya jaminan yang bersifat umum.

-Dalam hal kepastian hukum dan jaminan rasa aman bagi kreditor maka jaminan kebendaan adalah lebih kuat daripada jaminan perorangan,selain itu jaminan kebendaan memberikan hak preferen kepada kreditor pemegang hak jaminan kebendaan tersebut.

-Eksekusi benda jaminan pada perjanjian jaminan kebendaan dapat langsung dilaksanakan sesuai dengan aturan yang berlaku, sebaliknya pada jaminan perorangan eksekusi tidak dapat dilaksanakan dengan serta merta karena tidak ada benda yang bisa dijadikan obyek jaminan yang dapat dieksekusi 


\section{DAFTAR PUSTAKA}

Abdurrahman dan Samsul Wahidin, Beberapa Catatan Tentang Hukum Jaminan dan Hak- hak Jaminan Atas Tanah ,Alumni., Bandung , 1995.

Badrulzaman , Mariam Darus, Bab- bab tentang Hypotheek,PT Citra Aditya Bakti, Bandung, 2001.

Harsono , Boedi , Masalah Hipotek dan Credietverband, Kertas Kerja pada Seminar tentang Hipotik dan Lembaga - lembaga Jaminan lainnya , BPHN,Binacipta, Bandung, 1998.

Isnaeni, Moch , Hipotek Pesawat Udara di Indonesia, CV Dharma Muda, Surabaya, 2006.

Mertokusumo, Sudikno, Eksekusi Obyek Hak Tanggungan, Permasalahan dan Hambatan , Makalah pada Penataran Dosen Hukum Perdata Se- Indonesia Yogyakarta,Fakultas Hukum Universitas Gajah Mada.

Satrio, J, Hukum Jaminan, Hak- hak Jaminan Kebendaan , PT Citra Aditya Bakti, Bandung, 2003.

Sofwan, Sri Soedewi Masjchoen, Beberapa Masalah Pelaksanaan Lembaga Jaminan Khususnya Fidusia Di Dalam Praktek Pelaksanaannya Di Indonesia, ,Fakultas Hukum Universitas Gajah Mada, Yogyakarta, 1987,

Subekti, R, Jaminan - jaminan untuk Pemberian Kredit Menurut Hukum Indonesia, PT Citra Aditya Bakti, Bandung, 1997

Usman , Rachmadi, Pasal- pasal tentang Hak Tanggungan Atas Tanah, Djambatan , Jakarta, 2007. 